Security Co-operation between Russia and Ukraine in the Post-Soviet Era 


\section{Security Co-operation between Russia and Ukraine in the Post-Soviet Era}

Deborah Sanders

Defence Studies Department

Joint Services Command and Staff College 


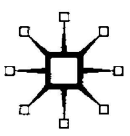

Deborah Sanders 2001

Softcover reprint of the hardcover 1st edition 2001 978-0-333-80095-9

All rights reserved. No reproduction, copy or transmission of this publication may be made without written permission.

No paragraph of this publication may be reproduced, copied or transmitted save with written permission or in accordance with the provisions of the Copyright, Designs and Patents Act 1988, or under the terms of any licence permitting limited copying issued by the Copyright Licensing Agency, 90 Tottenham Court Road, London W1T 4LP.

Any person who does any unauthorised act in relation to this publication may be liable to criminal prosecution and civil claims for damages.

The author has asserted her right to be identified as the author of this work in accordance with the Copyright, Designs and Patents Act 1988.

First published 2001 by

PALGRAVE

Houndmills, Basingstoke, Hampshire RG21 6XS and 175 Fifth Avenue, New York, N. Y. 10010

Companies and representatives throughout the world

PALGRAVE is the new global academic imprint of St. Martin's Press LLC Scholarly and Reference Division and Palgrave Publishers Ltd (formerly Macmillan Press Ltd).

ISBN 978-1-349-42086-5

ISBN 978-0-230-50521-6 (eBook)

DOI $10.1057 / 9780230505216$

This book is printed on paper suitable for recycling and made from fully managed and sustained forest sources.

A catalogue record for this book is available from the British Library.

Library of Congress Cataloging-in-Publication Data Sanders, Deborah, 1968-

Security co-operation between Russia and Ukraine in the post-Soviet era / by Deborah Sanders.

p. $\mathrm{cm}$.

Includes bibliographical references and index.

ISBN 978-1-349-42086-5

1. Russia (Federation)-Military relations-Ukraine.

2. Ukraine-Military relations-Russia (Federation) I. Title.

UA770.S255 2001

355'.031'094709477—dc21

2001032120

$\begin{array}{llllllllll}10 & 9 & 8 & 7 & 6 & 5 & 4 & 3 & 2 & 1\end{array}$

$\begin{array}{llllllllll}10 & 09 & 08 & 07 & 06 & 05 & 04 & 03 & 02 & 01\end{array}$ 
For my mother - whom every day I have to learn to live without 



\section{Contents}

Introduction 1

1 Security Co-operation: A Framework for Analysis 5

1. What does co-operation mean? 7

2. Factors that hamper and facilitate security co-operation 8

3. Barriers to co-operation 10

4. Facilitators of co-operation 16

$\begin{array}{ll}\text { Conclusion } & 20\end{array}$

2 Tactical Nuclear Weapons 23

1. Common interests in co-operation 25

2. Why did Ukraine halt the shipment of tactical nuclear weapons to Russia? $\quad 29$

3. Why did co-operation resume? 46

Conclusion $\quad 50$

3 Strategic Nuclear Weapons 5

1. Common interests in co-operation 54

2. Barriers to co-operation 61

3. Why did co-operation begin? $\quad 81$

$\begin{array}{ll}\text { Conclusion } & 94\end{array}$

4 The Black Sea Fleet 99

1. Common interests in co-operation 101

2. Why did co-operation prove so elusive? 108

3. Why did co-operation take place? 123

$\begin{array}{ll}\text { Conclusion } & 137\end{array}$

$\begin{array}{lc}\text { Conclusion } & 143\end{array}$

$\begin{array}{ll}\text { Notes } & 153\end{array}$

$\begin{array}{lr}\text { Bibliography } & 187\end{array}$

$\begin{array}{lr}\text { Index } & 199\end{array}$ 


\section{Acknowledgements}

I have many friends, colleagues and institutions to thank for their assistance in completing this book.

First, Aberystwyth University very kindly gave me a 'University of Wales' scholarship for the completion of my PhD. While at Aberystwyth University I received considerable support from the International Politics Department and most notably from my two excellent supervisors - Dr Jenny Mathers and Dr Nick Wheeler. Two very close and extremely supportive friends also helped me enormously with my PhD - Ms Sue Marlow and Dr Alan Collins.

Second, many colleagues at the Joint Services Command and Staff College have helped me more than they can imagine in turning the $\mathrm{PhD}$ into a book. Huge thanks go to Mr Stephen Prince, Dr Andrew Dorman and Professor Geoff Till. In addition, Dr Caroline KennedyPipe gave me some excellent advice about turning the PhD into a book.

Third, my thanks go to King's College London for giving me a sabbatical to finish the book.

Lastly, thank you Stephen for your unconditional love and support. 